\title{
Institutional Barriers to Climate Change Adaptation in Burkina Faso: How could We Go around Them?
}

\author{
Fiacre Basson $^{1,2,3}$, Djibril S. Dayamba ${ }^{4,5}$, Joel Korahire ${ }^{6}$, Jean M. Dipama ${ }^{2}$, François Zougmore ${ }^{1} \&$ Tiga Neya $^{7}$ \\ ${ }^{1}$ Materials and Environment Laboratory (LAME), Joseph Ki-ZERBO University of Ouagadougou, Burkina Faso \\ ${ }^{2}$ Laboratory of Studies and Research on Environment and Territories (LERMIT), Joseph Ki-ZERBO Uni-versity \\ of Ouagadougou, Burkina Faso \\ ${ }^{3}$ Deutsche Gesellschaft für Internationale Zusammenarbeit (GIZ) GmbH, Burkina Faso \\ ${ }^{4}$ Climate Analytics GmbH, Ouagadougou, Burkina Faso \\ ${ }^{5}$ Institut de l'Environnement et de Recherches Agricoles (INERA)/Saria, Burkina Faso \\ ${ }^{6}$ Institute of Society Sciences (INSS), Burkina Faso \\ ${ }^{7}$ Ministry of Environment, Green Economy and Climate Change, Burkina Faso \\ Correspondence: Fiacre Basson, Materials and Environment Laboratory (LAME), Joseph Ki-ZERBO University \\ of Ouagadougou, Burkina Faso. Tel: 2-267-135-6423. E-mail: basson_fiacre@yahoo.fr
}

Received: August 8, 2020

doi:10.5539/jsd.v13n5p67
Accepted: September 21, $2020 \quad$ Online Published: September 28, 2020

URL: https://doi.org/10.5539/jsd.v13n5p67

\begin{abstract}
Despite the existence of a National Adaptation Plan to climate change (NAP) in Burkina Faso, operationalizing adaptation still face a number of challenges. The current study focused on identifying institutional barriers to the strategic objectives of climate change adaptation (CCA) using a literature review and semi-structured interviews conducted with key stakeholders / resource persons involved in the implementation of the NAP. The results revealed a weak collaboration between the NAP steering institution and the ministerial departments covered by the NAP. This situation, first, hampers the implementation of adaptation actions and secondly, the monitoring reporting and verification of adaptation initiatives. Further, the analysis revealed that lack of financial resources poses constraints to many actions that were to be taken by the steering institution and therefore creates poor ownership of the NAP by the main stakeholders that should be actively involved in the NAP process. To cope with the various constraints, it is necessary to have strong political support in many aspects. For instance, it was judged that institutionalizing the role of climate change (CC) focal point within the ministries and embedding NAP monitoring and evaluation (M\&E) objectives and indicators with existing functional M\&E systems in the sectorial ministries will ease CCA actions integration in operational plans, their implementation and documentation. Moreover, it is relevant to have a continuous capacity building plan to keep stakeholders updated on climate change issues as this will support them in their mandate of mainstreaming CC into ministerial operational plans and lead to optimal CCA implementation and monitoring.
\end{abstract}

Keywords: adaptation, Burkina Faso, climate change, institutional barriers, national climate change adaptation plan

\section{Introduction}

Climate change (CC) is a worldwide concern affecting the environment, the economy as well as communities and their livelihoods (Intergovernmental Panel on Climate Change [IPCC], 2014). Developing countries are particularly vulnerable (Ayers, Huq, Wright, Faisal \& Hussain, 2014) because of their limited adaptive capacity and the dependence of their economies to climate-sensitive natural resources exploitation (Millner \&Dietz, 2015; Gadédjisso-Tossou, Egbendewe \& Abbey, 2016). Particularly, CC affects the living conditions of vulnerable groups and communities in developing countries (Pandey, Gupta \& Anderson, 2003; Nelson, 2011). Several studies have shown that, in the current setup (mode of living), climate change impacts are hardly avoidable and therefore require adaptation measures (Waongo, Lauxb \& Kunstmann, 2015; Touré, 2016; Otieno, Ogutu, Mburu \& Nyikal, 2017).

Climate change adaptation (CCA) has become an important component as a political priority in international 
negotiations in recent years (Burton, Huq, Lim, Pilifosova \& Schipper, 2002; Schipper, 2006). Among the important key decisions taken by United Nations Framework Convention on Climate Change (UNFCCC) to tackle the issue, is the adoption of its new vision to update National Climate Change Adaptation Plans (NAP) framework. Indeed, NAP process was adopted by Decision No. 5 of 17th UNFCCC Conference Of Parties (COP) to enable Least Developed Countries (LDCs) build their resilience to climate change impacts and to promote systematically the integration of climate risks and opportunities into existing planning systems. Therefore, several countries initiated (or are initiating) their adaptation strategies to cope with negative impacts of climate change (Swart et al., 2009).

Burkina Faso adopted its NAP in September 2015 to reduce its vulnerability to climate change. Within the framework of the elaboration of the NAP, a number of studies were conducted on the exposure of the country to climate change, its impacts and existing adaptive capacities. Climate projections in Burkina Faso, done during the NAP elaboration process, showed a high degree of uncertainty for future rainfall trends, an increase in temperature from 2.5 to $5^{\circ} \mathrm{C}$, an increase of potential evapotranspiration from 2 to $10 \mathrm{~mm}$ and a higer frequency of extreme climate events such as droughts and floods in 2050 (Laboratory for Mathematical Analysis of Equations [LAME], 2012). More recent studies (Salack et al., 2015; Panthou et al., 2018; Lejeune \&Saeed, 2019;) confirm the uncertainty of future evolution of mean annual precipitation but also an increase in temperature and higher frequency and intensity of extreme events (flood and drought). This could cause several consequences such as economy decline in general (Zidouemba, 2017; Schleypen, Saeed, Dayamba, Coulibaly \& D'haen, 2019) agricultural production decrease (Jalloh, Nelson, Thomas, Zougmoré \& Roy-Macauley, 2013) and huge income losses in agriculture and livestock sectors (Ouédraogo, 2012; Traoré \& Owiyo, 2013; Dayamba, D'haen, Coulibaly \& Korahiré, 2019). This will also have repercussions on food and health security for most vulnerable rural populations.

It has been reported that leadership, organizational structure, collaboration and networking, stakeholder commitment and access to relevant information are common characteristics for communities that plan successfully their adaptation process. However, there are many barriers that can impede the development and implementation of CCA measures (Adger et al., 2007). It is widely recognized that institutional and social factors, deficient financial resources, limited coordination within and between government and lack of political leadership are the commons obstacles (Bryan, Deressa, Gbetibouo \& Ringler, 2009; Measham et al., 2011; Uittenbroek, 2016; Mees, 2017). Most of the problems in implementing the adaptation process are found in both developed and developing countries. Among the barriers, political and institutional factors have so far received little attention in research (Biesbroek, Kabat \& Klostermann, 2009; Dovers \& Hezri, 2010). Also, few studies have addressed determinants of the implementation of CCA initiatives among public climate policy actors.

The barriers reported in the literature may differ depending on the objective of the adaptation and the context in which the adaptation takes place (Adger, Lorenzoni \& O'Brien, 2009). The field of research on barriers to adaptation can evolve and Biesbroek (2014) confirms that adaptation is a multidimensional and possibly chaotic process and therefore the understanding of barriers to adaptation must also evolve to give it scientific legitimacy. Moreover, because of the specificity of each country, designing solutions to relieve the different barriers requires assessment of the issues at the local level (national, regional, etc.).

A recent work (Theokritoff \& D'haen, 2019) assessed policy aspects of CCA issues in Burkina Faso namely by examining the status / process of integration of CC into national adaptation and development policies. The current paper explored the barriers to CCA through an analysis of how effective / efficient is the interaction / coordination between NAP keys stakeholders. Specifically, it aimed to 1) highlight difficulties around implementation of the NAP (i.e., translation into operational plans); 2) understand the functioning of the coordination and guidance framework for NAP actions and 3) analyze the monitoring-evaluation of the sectorial and global NAP. Results from this study might guide Burkina Faso during the revision of the NAP as the current one is supposed to be updated after 2020. Also, lessons learnt may inform countries in the sub-Saharan region as Burkina Faso is one of the first countries having developed a global and sectorial NAPs.

\section{Methodology}

\subsection{Study Area/Context}

Burkina Faso belongs to the group of Least Developed Countries (LDCs) and is located in the heart of West Africa with an area of approximately $274,000 \mathrm{~km}^{2}$. It has an estimated population of about 19 million people with an annual population growth rate of 3\% in 2016 (National Institute of Statistics and Demography [INSD], 2017). The climate is of tropical type characterized by a short rainy season which generally extends from June to October and a long dry season from November to May (Ibrahim, Polcher, Karambiri, Yacouba \& Ribstein, 2014). According to 
the same authors, the average annual rainfall varies between $1100 \mathrm{~mm}$ and $500 \mathrm{~mm}$ from south to north. The rural sector plays a major role in the national economy. Indeed, it essentially comprises agricultural, pastoral and forestry activities, which account for 40 per cent of the gross domestic product (GDP) and employs about 80 per cent of the active population (Zidouemba \& Gerard, 2018).

Burkina Faso has developed its NAP based on six sectorial adaptation plans (agriculture, animal resources, environment and natural resources, energy, health, infrastructure and habitat) including cross-cutting issues (women's associations, civil society organizations and water security). The Ministry of Environment, Green Economy and Climate Change (MEEVCC) coordinates the NAP through the Permanent Secretariat of the National Council for Sustainable Development (SP-CNDD), which houses the UNFCCC Focal Point. The governance bodies of the NAP coordination remain the monitoring-evaluation focal points in the ministerial sectors covered by the NAP and the monitoring-evaluation unit of the SP-CNDD. Within the framework of the implementation of the NAP, Burkina Faso has been supported since 2018 by the project of Scientific Support for National Adaptation Plan Processes (PAS-PNA). Funded by the German Federal Ministry for the Environment, Nature Protection and Nuclear Safety (BMU), the PAS-PNA is implemented by Deutsche Gesellschaft für Internationale Zusammenarbeit (GIZ) in collaboration with Climate Analytics under the supervision of the MEEVCC.

\subsection{Literature Review}

The literature search focused on national climate policies and the existing literature on institutional and policy aspects, including articles and doctoral theses. It made it possible to obtain a wide range of national documents, including the global and sectorial NAPs, the NAP implementation report (covering the period 2015-2018), the legal / regulatory texts of the SP-CNDD and activities' reports. A general search on Google Scholar was done for scientific documents using the following keywords in French and English: "challenges", "limits", "constraints", "barriers" to adaptation to climate change. The literature review contributed to refining the methodological approach of the study and guided the elaboration of the questionnaires which were, later on, used for the interviews with some national key resource persons in the field of climate change governance.

\subsection{Stakeholders' Knowledge and Perception on NAPs}

Before assessing stakeholders' perceptions on the institutional barriers to CCA, it appeared important to first have an overall idea of their knowledge on the issue of climate change (and guiding documents) as lack of such knowledge, per se, could exacerbate the institutional barriers. In this study, stakeholders' knowledge on climate change, global and sectorial NAPs were assessed, using the following criteria:

- $\quad$ Nil= interviewee is not informed of the existence of the global NAP and the sectorial NAP (though aware of $\mathrm{CC}$ ); therefore, he / she has no knowledge of the content of these documents;

- Low= respondent perceived risks associated with climate change. He / she is informed of the existence of the global NAP or the sectorial NAP but does not have a good understanding of their content;

- Medium= interviewee has knowledge of either the global NAP or the sector NAP. He / she also has some knowledge of the content of the global NAP or sectorial NAP focused on vulnerable sectors and aspects of climate change being addressed;

- High= interviewee has good ownership of the global NAP and the sectorial NAP as well as their content in terms of the vulnerable sectors and projects/interventions mentioned for adaptation to climate change.

The interviews focused on keys stakeholders involved in NAP implementation such as SP-CNDD and ministerial directorates (Table 1). Except SP-CNDD with its 15 interviewees, the number of interview participants varied between two (02) and five (05) people depending on the institution met. These interviews were organized with the staffs of the steering institution of the NAP which is the SP-CNDD and the 7 technical planning departments of the ministries covered by the NAP, notably MEEVCC, Ministry of Agriculture and Hydro-Agricultural Development (MAAHA), Ministry of Health (MS), Ministry of Water and Sanitation (MEA), Ministry of Energy (ME), Ministry of Animal Resources and Fisheries (MRAH), Ministry of Infrastructure (MI). 
Table 1. Stakeholders surveyed by institution

\begin{tabular}{lccc}
\hline Institutions & Man & Woman & Total \\
\hline Ministry of agriculture (MAAHA) & 3 & 2 & 5 \\
Ministry of Animal resources (MRAH) & 2 & 2 & 4 \\
Ministry of Environment (MEEVCC) & 5 & 0 & 5 \\
Ministry of Water Resources (MEA) & 4 & 1 & 5 \\
Ministry of Energy (ME) & 4 & 0 & 4 \\
Ministry of Infrastructure (MI) & 1 & 2 & 3 \\
SP-CNDD & 10 & 5 & 15 \\
Ministry of Health (MS) & 2 & 1 & 3 \\
Total & $\mathbf{3 1}$ & $\mathbf{1 3}$ & $\mathbf{4 4}$ \\
\hline
\end{tabular}

\subsection{Barriers Identification}

The qualitative research method is increasingly applied in many areas of social science (Lehmann, Brenck, Gebhardt, Schaller \& Süßbauer, 2015; Swai, 2017; Davies et al., 2020). Indeed, it gives a social representation rather than a simple statistical data (Cresswell, 2013). Several authors have used key resource persons interviews based on structured questionnaires to collect qualitative data (Kabisch et al., 2017; Ahenkan, Jane Osei \& Owusu, 2018; Glasgow, Lan-gaigne, Thomas, Harvey \& Campbell, 2018; Clar \& Steurer, 2019). Such method relies on the confirmed / supposed knowledge of the interviewee of the subject he / she is being interviewed on; therefore, sample size is most often not very high. For instance, the interviewees were around 34 for Kabisch et al. (2017), 24 for Ahenkan et al. (2018), 18 for Glasgow et al. (2018) and 35 for Clar \& Steurer (2019).

In our study, the identification of barriers to adaptation consisted of semi-structured interviews conducted during the month of July 2018. Interviews were conducted with forty-four (44) public administration experts responsible for planning at the central level of the country (Table 1). These experts were selected because they are key stakeholders in the governance of adaptation in Burkina Faso; they define sectorial policy letters and multi-year planning documents. They are also responsible for monitoring and evaluating policies (including climate ones) in priority sectors vulnerable to climate change. Also, the level of adaptation knowledge of these experts can influence other actors to change their daily practices through awareness raising and the dissemination of information (Lebel, Manuta \& Garden, 2011). The interviews were conducted using a guide based on nine (09) to eleven (11) semistructured questions, depending on the institution targeted. These questions focused mainly on the NAP's organizational mechanism, the interaction between partner institutions, the mechanism put in place to coordinate the implementation of the global NAP and sectorial NAPs, as well as the weaknesses and actions to improve the NAP process. Also, information was collected on the climate actions carried out.

The SP-CNDD facilitated the various interviews by writing an administrative note requesting / encouraging the different institutions to participate to the survey. Following the note, the different institutions were contacted by telephone calls to agree on a schedule for conducting the interviews. According to Denscombe (2014) these approaches should have increased the credibility of the study, generated strong participation and ensured the availability of actors (Jupp, 2006). All interviews were conducted face-to-face, building trust with interviewees.

\subsection{Data Analysis}

The data were analyzed looking at the effectiveness/efficiency of the collaboration between institutions (SP-CNDD and partner institutions), and particularly how this support stakeholders' knowledge of the NAP, the state of implementation of the NAP (translation into stakeholders' operational planning processes) and the effectiveness of the monitoring-evaluation of adaptation actions. The preliminary results of the study were also shared in the form of communications with stakeholders during various workshops organized by the SP-CNDD and its partners to collect feedbacks (Morce, Barrett, Mayan, Olson \& Spiers, 2002). The relative importance of barriers was obtained by summing total number of respondents per barrier.

\section{Results}

\subsection{Stakeholders Knowledge on Adaptation Planning Documents (NAPS)}

The consequences of climate change, characterized by threats to natural, economic and human systems, are well understood by most stakeholders. They also confirmed the vulnerability of the 7 priority sectors to climate change 
considered by the NAP. However, the results in Figure 1, show that the level of knowledge of the adaptation plan, whether national or sectorial, varies from nil to medium. Thus, $54 \%$ of respondents have a medium level of knowledge versus $7 \%$ nil and $39 \%$ low. This, per se, can be seen as a barrier to optimal implementation of CCA.

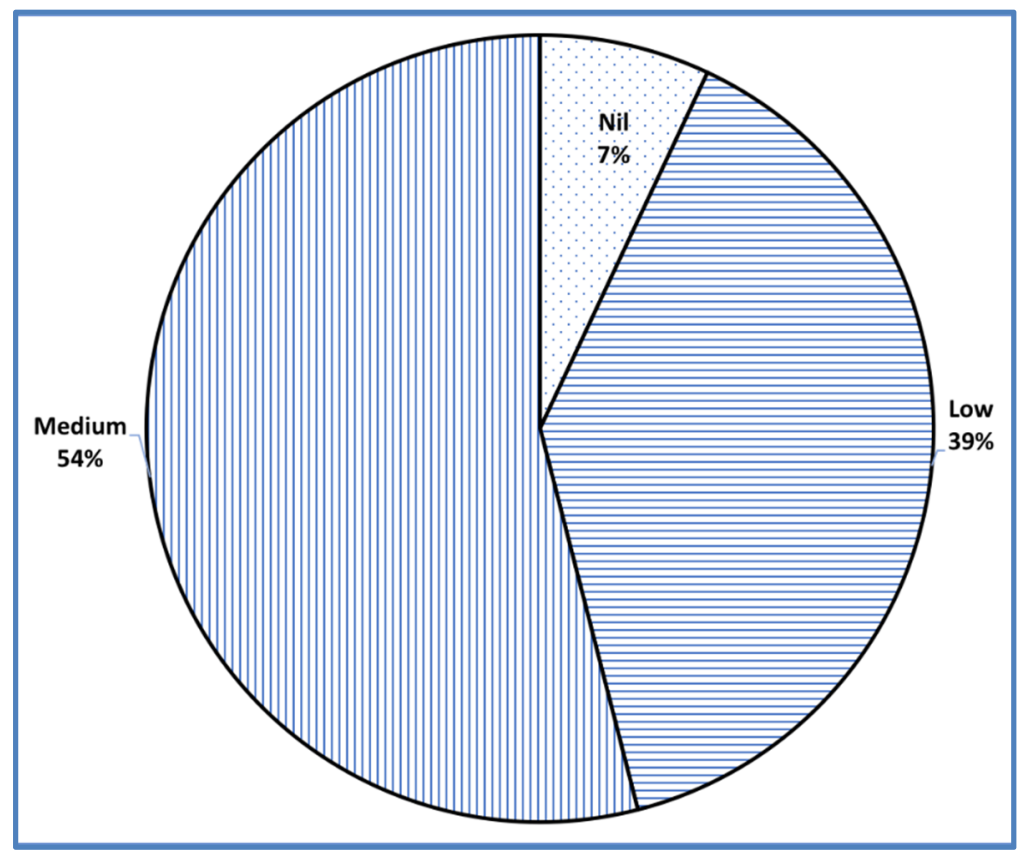

Figure 1. Stakeholders knowledge on NAPs

\subsection{Barriers to Climate Change Adaptation}

The barriers to climate change adaptation identified can be grouped into five key themes, notably the lack of an inter-sectorial coordination mechanism, insufficient communication, low use of sectorial NAPs in operational planning, weak financial and human resources, and malfunction of the NAP monitoring-evaluation system, all of which are linked / related to institutional aspects.

\subsubsection{Lack of an Inter-sectorial Coordination Mechanism}

All interviewees (100\%) noted the lack of a framework for consultation between the SP-CNDD and the sectorial actors of the NAP. This is materialized by the poor communication between different stakeholders in the implementation of the NAP and the inexistence of a channel for the feedback of information from the sectorial ministries to the SP-CNDD as well as the lack of formal collaboration between the SP-CNDD and the sectorial actors. Indeed, stakeholders said they felt the lack of collaboration because since the validation of the NAP in September 2015, there has been not much information from SP-CNDD, nor was a capacity building initiated to support actors in better understanding the matters and mainstreaming them into sectors' operations. Moreover, they also think that the NAP steering institution (SP-CNDD) has favored/played a sectorial role (focusing on the ministry of Environment to which it belongs) instead of a role of an inter-sectorial coordination institution.

\subsubsection{Insufficient Communication}

Information plays a key role in the implementation of adaptation measures. Leaflets and fact sheets as well as the NAP summary for decision-makers are the main outreach tools developed. Indeed, according to NAP steering institution, these tools have contributed to improving communication about the NAP. However, $91 \%$ of the stakeholders judged that the communication between the various stakeholders involved in the implementation of the NAP was poor. It appears that communication material was produced but the effort to share it with stakeholders was insufficient.

\subsubsection{Low Use of Sectorial NAPs in Operational Planning}

Each sectorial ministry has an adaptation policy document that describes, among other things, the extent and impacts of climate change and adaptation measures. Within these institutions, most development planning agents $(89 \%)$ reported that they do not consider sectorial NAPs in the development of their operational planning tools. In addition, it was found that most planning agents have limited knowledge of the sectorial NAPs and climate 
change. However, some sectorial ministries, in the implementation of their projects, are integrating adaptation measures (already listed in the sectorial NAPs) without linking them to the NAP. For instance, actions undertaken in the sectors (considered by the NAP) are climate-smart agro-sylvo-pastoral practices, diversification of energy sources, capacity building and water management as well as energy efficiency, although they are not, per se, documented as climate action.

\subsubsection{Weak Financial and Human Resources}

The overall cost of implementing the NAP for the period 2015-2020 was $\$ 6,410,582,870$. This amount was to be mobilized from several sources of funding, including national budget, private sector and civil society, as well as technical and financial partners. Unfortunately, the NAP implementation process continues to be challenged by the lack of financial and human resources. Indeed, $75 \%$ of the respondents stated that institutions do not have sufficient financial resources and human expertise for the implementation of adaptation actions. In the same vein, the decentralized State institutions in charge of statistical studies often do not have the logistics for mobility / transport (cars, moto), fuel and computer equipment essential for data collection in the field and data storage/management.

\subsubsection{Malfunction of the NAP Monitoring-Evaluation System}

The NAP states the importance and need for a monitoring and evaluation system to track progress and performance in adaptation planning and implementation. Indeed, it specifies, depending on the central or ministerial level, the monitoring-evaluation methodology and the resources required. Notwithstanding the importance of monitoring and evaluation in the NAP process, most of the actors $(68 \%)$ mentioned that no mechanism has, so far, been functional.

\section{Discussion}

The global National Adaptation Plan (NAP) and sectorial NAPs remain climate planning policy documents that capture well the problems caused by climate change and potential interventions. Most institutional actors are relatively aware of the inevitable impacts induced by climate change and recognize the need to adapt. They noted the relevance of having a main governance institution such as the SP-CNDD mandated for the coordination of climate actions. The importance of a national authority in charge of horizontal and vertical coordination has previously been stressed (Bulkeley \& Betsill, 2005). Unfortunately, our results established that the implementation of climate change adaptation actions remains limited by, among other things, the lack of an optimal coordination mechanism between sectorial ministries. Other studies also led to similar barriers related to responsibilities sharing or actions coordination between different decision-making levels and administrative units that hinder adaptation actions implementation (Moser \& Ekstrom, 2010; Bertrand \& Richard, 2012; Cuevas, Peterson, Robinson, \& Morrison, 2015; Davies et al., 2020). Particularly, because of the cross-sectorial and cross-cutting nature of climate change, coordination is essential to facilitate the integration of climate policies into development planning and budgeting processes (Urwin \& Jordan, 2008; Jordan \& Lenschow, 2010, Adelle \& Russell, 2013). Moreover, to achieve effectiveness and synergy in mainstreaming CCA actions into national development efforts, coordination mechanism must inexorably involve representatives of all key sectors, civil society and financial partners. To support in such inter-sectorial coordination a new initiative "Transparency capacity-building mechanism", which was created at the 21 st COP in Paris for institutional and technical capacity building on transparency of climate information, seems to be well on time, with Burkina Faso recently launching activities under this initiative.

The NAP implementation is based on the accountability of actors and the coherence of their interventions as well as partnership, which are the essential guiding principles for ensuring ownership and sustainability of interventions by stakeholders. However, the absence of formal and functional Focal Points in the sectorial ministries as highlighted by stakeholders, is a major limiting factor for such coordination. Indeed, these Focal Points, as watchdogs in the annual planning process of their respective ministries, could have played a fundamental role in the proper circulation of climate information, the integration of CCA in operational plans and thus, the implementation of the NAP.

The lack of coordination noted in our study includes the absence of training for stakeholders (thus, the insufficient knowledge as seen in the results) leading to the lack of collaboration, which according to some authors (Moser \& Ekstrom, 2010; Lemieux \& Scott 2011; Flugman, Mozumder \& Randhir, 2012; Waters, Barnett \& Puleston, 2014; Davies et al. 2020) leads to poor judgments and choices as well as negligence on the part of the various stakeholders. This situation is exacerbated by the high staff turnover (mobility of human resources) at key positions within ministerial departments, which hinders the continuity of the initiatives / discussions especially because trained staffs that quit their position never transfer skills and knowledge to the actors who take over (the administrative system even seems to lack a proper mechanism for doing so). This partly explains the difficulties 
encountered by the NAP steering institution in the feedback and circulation of information related to the implementation of the NAP. Moreover, the capitalization and learning that should inspire operational planning at the level of the sectorial ministries and govern / guide a future possible revision of the NAP is proving to be complicated.

Thus, the absence of a monitoring scheme at the sectorial level has not facilitated communication between the sectorial ministries and the SP-CNDD. In addition, the indicators designed to measure progress of the NAP process (as can be found in the document itself) lack precision in terms of calculation, reference values and targets (Sombié, 2019). In the same sense, the range of activities to be carried out by a diversity of government actors, the private sector, development partners, civil society organizations and local authorities makes it more difficult to monitor and evaluate CCA actions. This has had a real impact on the monitoring and evaluation of the implementation of the NAP. In this context, it is important that the NAP be truly integrated into the existing internal monitoring mechanism of the sectorial ministries (and not duplicate mechanisms) to ensure that climate actions are monitored.

As an illustration, already existing monitoring platforms and databases are, among others, the Integrated Monitoring and Evaluation System of the National Water Strategy (DISESNE); the National Observatory for the Environment and Sustainable Development (ONEDD); the Information, Planning and Results Monitoring and Evaluation System (SIPSER) and the Urban Information System (SIU). Aligning the NAP's monitoring and evaluation (M\&E) system with existing mechanisms will make it possible to have a unique simple, effective, less costly and sustainable M\&E system. Overcoming this challenge will make it possible to integrate the local level information into this M\&E system and to capitalize on the actions of other non-state actors. Actors could use the national catalogue of development indicators developed since 2010 for the planning and M\&E of policies, projects and programmes. This could contribute to better monitoring the progress and performance of climate change actions.

The interviews carried out highlighted both insufficient communication around the NAP and between key NAP stakeholders. This has consequences in terms of lack of ownership of the NAP by actors in the sectorial ministries and the use of its orientations in operational planning. The poor communication could be due to the lack of definition of a medium and long-term communication strategy for the NAP. It could also be explained by the fact that the main stakeholders involved in the development of the NAP have not developed a concerted and appropriate methodology for operationalizing the sectorial NAPs. This weakness in institutional interactions is also aggravated by the lack of constraining policy. Indeed, Burkina Faso has no formal regulation requiring stakeholders to specifically include adaptation to climate change in their sectorial activities (as it is for sustainable development, materialized in Sustainable Development Policy Act / Loi d'orientation sur le Development Durable). This policy void can make communication between actors more difficult insofar as there are no shared values, rules and principles on adaptation.

CCA requires not only knowledge exchange between diverse stakeholders but also the institutionalization of regular meetings that promote the co-construction of knowledge and the development of sustainable capacity for action (Shaw, Chiara \& Stocker, 2013; Sternlieb, Bixler, Huber-Stearns \& Huayhuaca, 2013). For Burkina Faso, it should be based on i) the organization of information, sensitization and ownership actions through better communication on the NAP, ii) the setting up of an information platform, iii) the institutionalization of the role of Focal Point in the ministries, which will enable operationalization through the provision of resources to carry out their tasks and iv) continuous capacity building in terms of knowledge on climate change and the NAP to keep stakeholders updated on the subject. The results also report the absence of a budget allocated to the overall NAP and sectorial NAPs. This is in line with the conclusions of other studies that have highlighted the inadequacy of funding for the implementation of adaptation (Burch, 2010; Biesbroek, Klostermann, Termeer \& Kabat, 2013; Cuevas et al., 2015) The low level of funding for the NAP is explained by the lack of a funding strategy or a longterm investment plan for adaptation measures. Also, the NAP is one of the tools for operationalizing the National Economic and Social Development Plan (PNDES), which is also encountering difficulties in mobilizing the funding announced for its implementation. The actors interviewed noted the low level of financial resource mobilization and access to climate funds, mainly due to the complexity of the financial mechanisms and the slow process of most international funding mechanisms. They also mentioned that there is no specific national budget allocated to the NAP. In general, the lack of financial resources within the public administration is said to be linked to the lack of qualified expertise to capture the various funding opportunities. As a result, the Ministry in charge of the Economy must be better sensitized on the economic challenges of climate change and be better involved in resources mobilization for climate purpose.

Several authors note that in countries where material and financial resources are scarce, their availability and accessibility constitute major obstacles in the development of adaptation strategies (Bryan et al., 2009; Amundsen, 
Frode \& Hege, 2010; Dovers \& Hezri, 2010; Davies et al., 2020). In a context where Burkinabe State budget will have difficulties making a significant share available for climate actions, given priorities of the moment (security, health, education, etc.), it is essential that the actors of the sector take advantage of the international financial mechanisms, in particular those of the UNFCCC. Burkina Faso is undertaking many efforts in this direction, mainly through the existence of a Green Climate Fund (GCF) Executive Secretariat and the Designated National Authority for the GCF, the development of the GCF country programme and advocacy techniques as well as capacity building of stakeholders on the development of solid / relevant project proposals. Efforts are also underway to initiate the process of accreditation of the Environmental Intervention Fund (FIE) and a private Bank (Coris Bank International - CBI) as National Implementing Entities for the GCF. Thus, the accreditation of the FIE and CBI will not only contribute to the appropriation of climate finance mechanisms at the international level but also to the mobilization of financial resources through the development of bankable projects.

\section{Conclusion}

Climate change is already having a negative impact in Burkina Faso and its projected impacts would be amplified in the future. The development and implementation of CCA measures is essential to set the country's socioeconomic development on a sustainable trajectory. However, the implementation of climate actions usually encounters several difficulties. This study has highlighted five main interlinked obstacles to CCA particularly focusing on institutional ones, including insufficient collaboration between NAP stakeholders, insufficient communication, weak ownership of NAP by sectorial ministries (low use in operational planning), insufficient financial resources (which also stems from institutional weakness in this field) and the malfunctioning of monitoring and evaluation mechanism for adaptation actions. In this regard, it was recommended to carry out actions focused on (i) strengthening the institutional structure and coordination mechanisms - one key point being to formalize the role of Focal Point (FP) in the sectorial ministries which also goes with allocation of resources to the FP for implementing his/her tasks; (ii) operationalizing the monitoring and evaluation system through, for instance, embedding it in existing mechanisms; (iii) mobilizing resources for the implementation of the NAP by strengthening stakeholders' (individuals and institutions) capacities on climate projects development and management and (iv) developing a workable NAP implementation plan. Our study focused mainly on State actors (the ministries) and we recommend that certain topics deserve further attention, in particular: (i) to deepen the study by including other actors in the NAP process (Civil Society, research institutions, development agencies) for a comparative analysis to highlight differences in the main barriers to adaptation and (ii) to apprehend the meaning/extent attributed to the concept of "barriers" by practitioners. This would create a better understanding (perspectives of ground actors) of the main barriers to operational mechanisms of adaptation governance. Such survey can target municipalities and projects that implement adaptation initiatives and will therefore make it possible to have more quantitative results to complement our more quality oriented study.

\section{Acknowledgments}

This study was conducted under the BMU-funded project "Projet d'Appui Scientifique aux processus de Plans Nationaux d'Adaptation (PAS-PNA) dans les pays francophones les moins avancés d'Afrique subsaharienne". The authors appreciate the support of Nele Buenner, project manager PAS-PNA. They also acknowledge the NAP stakeholders for their participation to the various interviews conducted.

\section{References}

Adelle, C., \& Russel, D. (2013). Climate Policy Integration: A Case of Déjà Vu? Environmental Policy and Governance, 23, 1-12. https://doi.org/10.1002/eet.1601

Adger, W. N., Agrawala, S. Mirza, M. M. Q., Conde, C., O’Brien, K., Pulhin, J., Pul-warty, R., Smit, B., ... Takahashi, K. (2007). Assessment of adaptation practices, options, constraints and capacity. Climate Change 2007: Impacts, Adaptation and Vulnerability. In M. L. Parry, O. F. Canziani, J. P. Palutikof, P. J. van der Linden, \& C. E. Hanson (Eds.), Contribution of Working Group II to the Fourth Assessment Report of the Intergovernmental Panel on Climate Change (pp. 717-743). Cambridge, UK: Cambridge University Press.

Adger, W. N., Lorenzoni, I., \& O'Brien, K. (2009). Adapting to climate change: thresholds, values, governance. Cambridge University Press, Cambridge, UK. http://dx.doi.org/10.1017/cbo9780511596667

Ahenkan, A., Jane Osei, J., \& Owusu, E., H. (2018). Mainstreaming Green Economy: An Assessment of Private Sector Led Initiatives in Climate Change Adaptation in Ghana. Journal of Sustainable Development, 11(2), 2018. https://doi.org/10.5539/jsd.v11n2p77

Amundsen, H., Frode, B., \& Hege, W. (2010). "Overcoming barriers to climate change adaptation: a question of multilevel governance?" Environment and Planning C: Government and Policy, 28, 276-289. 
https://doi.org/10.1068/c0941

Ayers, J., Huq, S., Wright, H., Faisal, A. M., \& Hussain, S. T. (2014). Mainstreaming Climate Change Adaptation into Development in Bangladesh. Climate and Development, 6(4), 293-305. https://doi.org/10.1080/17565529.2014.977761

Bertrand, F., \& Richard, E. (2012). Les initiatives d'adaptation aux changements climatiques : entre maintien des logiques de développement et renforcement des coopérations entre territoires. Territoire en Mouvement $\mathrm{n}^{\circ}$ 14 et 15 « Inégalités et iniquités face aux changements climatiques ». https://doi.org/10.4000/tem.1799

Biesbroek, G. R. (2014). Challenging barriers in the governance of climate change adaptation. (Doctoral dissertation, Wageningen University, Pays-Bas). Retrieved from https://library.wur.nl/WebQuery/wurpubs/fulltext/290520

Biesbroek, G. R., Klostermann, J. E. M., Termeer, C. J. A. M., \& Kabat, P. (2013). On the nature of barriers to climate change adaptation. Regional Environmental Change, 13(5), 1119- 1129. https://doi.org/10.1007/s10113-013-0421-y

Biesbroek, G., Kabat, P., \& Klostermann, J. (2009). Institutional governance barriers for the development and implementation of climate adaptation strategies. Paper presented at the Earth System governance: People, Places and the Planet. Retrieved from http://www.earthsystemgovernance.org/ac2009/papers/AC20090044.pdf

Bryan, E., Deressa, T. T., Gbetibouo, G. A., \& Ringler, C. (2009). Adaptation to climate change in Ethiopia and South Africa: options and constraints. Environmental Science and Policy, 12(4), 413-426. https://doi.org/10.1016/j.envsci.2008.11.002

Bulkeley, H., \& Betsill, M. (2005). Rethinking sustainable cities: multilevel govern-ance and the urban politics of climate change. Environmental Politics, 14(1), 42-63. https://doi.org/10.1080/0964401042000310178

Burch, S. (2010). Transforming barriers into enablers of action on climate change: Insights from three municipal case studies in British Columbia, Canada. Global Environmental Change, 20(2), 287-297. https://doi.org/10.1016/j.gloenvcha.2009.11.009

Burton, I., Huq, S., Lim, B., Pilifosova, O., \& Schipper, E. L. (2002). From impacts assessment to adaptation priorities: the shaping of adaptation policy. Climate Policy, 2(2-3), 145-159. https://doi.org/10.3763/cpol.2002.0217

Clar, C., \& Steurer, R. (2019). Climate change adaptation at different levels of government: Characteristics and conditions of policy change. Natural Resources Forum, 43, 121-131. https://oi.org/10.1111/14778947.12168

Creswell, J. W. (2013). Research design: Qualitative, quantitative and mixed methods approaches (3rd ed.). Thousand Oaks, CA: Sage Publications Incorporated.

Cuevas, S. C., Peterson, A., Robinson, C., \& Morrison, T. H. (2015). Institutional Capacity for Long-Term Climate Change Adaptation: Evidence from Land Use Planning in Albay, Philippines. Regional Environmental Change. https://doi.org/10.1007/s10113-015-0909-8

Davies, J. E., Spear, D., Ziervogel, G., Hegga, S., Angula, M. N., Kunamwene, I., ... Togarepi, C. (2020). Avenues of understanding: mapping the intersecting barriers to adaptation in Namibia. Climate and Development, 12(3), 268-280. https://doi.org/10.1080/17565529-2019-1613952

Dayamba, S. D., D’haen, S., Coulibaly, O. J. D., \& Korahiré, J. A. (2019). Étude de la vulnérabilité des systèmes de production agro-sylvo-pastoraux face aux changements climatiques dans les provinces du Houet et du Tuy au Burkina Faso. Report produced under the project "Projet d'Appui Scientifique aux processus de Plans Nationaux d'Adaptation dans les pays francophones les moins avancés d'Afrique subsaharienne", Climate Analytics gGmbH, Berlin. https://doi.org/10.13140/RG.2.2.19258.95683

Denscombe, M. (2014). The good research guide: for small-scale social research projects. McGraw-Hill Education (UK).

Dovers, S. R., \& Hezri, A. A. (2010). Institutions and policy processes: the means to the ends of adaptation. WIREs Climate Change, 1, 212-231. https://doi.org/10.1002/wcc.29

Flugman, E., Mozumder, P., \& Randhir, T. (2012). Facilitating adaptation to global climate change: perspectives from experts and decision makers serving the Florida Keys. Climate Change, 112(3-4), 1015-1035. https://doi.org/10.1007/s10584-011-0256-9 
Gadédjisso-Tossou, A., Egbendewe, A. Y. G., \& Abbey, G. A. (2016). Assessing the Impact of Climate Change On Smallholder Farmers' Crop Net Revenue in Togo. Journal of Agriculture and Environment for International Development, 110(2), 229-248. https://doi.org/10.12895/jaeid.20162.453

Glasgow, L., Lan-gaigne, B., Thomas, C., Harvey, O., \& Campbell, E. A. (2018). Public Knowledge and Attitudes towards Climate Change and Its Impacts on Ecosystems in Grenada. American Journal of Climate Change, 7, 600-610. https://doi.org/10.4236/ajcc.2018.74037

Ibrahim, B., Polcher, J., Karambiri, H., Yacouba, H., \& Ribstein, P. (2014). Changes in rainfall regime over Burkina Faso under the climate change conditions simulated by 5 re-gional climate models. Climate Dynamics, 42 , 1363-1381. https://doi.org/10.1007/s00382-013-1837-2

IPCC. (2014). Part A: Global and sectorial aspects. (Contribution of working group II to the fifth assessment report of the intergovernmental panel on climate change). Climate Change 2014: Impacts, Adaptation, and Vulnerability, 1132. Genève (Suisse). Retrieved from https://www.ipcc.ch/pdf/assessmentreport/ar5/wg2/WGIIAR5-FrontMatterA_FINAL.pdf

Jalloh, A., Nelson, G. C., Thomas, T. S., Zougmoré, R., \& Roy-Macauley, H. (2013). West African agriculture and climate change: A comprehensive analysis. Washington, DC: International Food Policy Research Institute. https://dx.doi.org/10.2499/9780896292048

Jordan, A.J., \& Lenschow, A. (2010). Environmental Policy Integration: A State of the Art Review. Environmental Policy and Governance, 20(3), 147-158. https://doi.org/10.1002/eet.539

Jupp, V. (2006). The Sage dictionary of social research methods. Sage. https://dx.doi.org/10.4135/9780857020116

Kabisch, N., Frantzeskaki, N., Pauleit, S., Naumann, S., Davis, M., Artmann, M., ... Bonn, A. (2016). Nature-based solutions to climate change mitigation and adaptation in urban areas: perspectives on indicators, knowledge gaps, barriers, and opportunities for action. Ecology and Society, 21(2), 39. http://dx.doi.org/10.5751/ES08373-210239

Kitchin, R., \& Tate, N. J. (2000). Conducting reseach in human geography: Theory, methodology and practice. Pearson Education Limited, Essex.

Laboratory for Mathematical Analysis of Equations [LAME]. (2012). Elaboration du PANA Programmatique du Burkina Faso : Etudes de modélisation climatique, d'évaluation des risques et analyse de la vulnérabilité aux changements climatiques. Les projections de climat futur au Burkina Faso. LAME, Unité de Formation et de Recherche en Sciences Exactes et Appliquées, Université de Ouagadougou.

Lebel, L., Manuta, J. B., \& Garden, P. (2011). Institutional traps and vulnerability to changes in climate and flood regimes in Thailand. Regional Environmental Change, 11, 45-58. https://doi.org/10.1007/s10113-010-01184

Lehmann, P., Brenck, M., Gebhardt, O., Schaller, S., \& Süßbauer, E. (2015). Barriers and opportunities for urban adaptation planning: analytical framework and evidence from cities in Latin America and Germany. Mitigation and Adaptation Strategies for Global Change, 20(1), 75-97. https://doi.org/10.1007/s11027-0139480-0

Lejeune, Q., \& Saeed, F. (2019). Étude de l'impact des changements climatiques futurs sur les ressources en eau au Burkina Faso. Report produced under the PAS-PNA project. Climate Analytics GmbH, Berlin.

Lemieux, C. J., \& Scott, D. J. (2011). Changing climate, challenging choices: Identifying and evaluating climate change adaptation options for protected areas management in Ontario, Canada. Environmental Management, 48(4), 675-690. https://doi.org/10.1007/s00267-011-9700-x

Measham, T. G., Preston, B. L., Smith, T. F., Brooke, C., Gorddard, R., Withycombe, G., ... Morrison, C. (2011). Adapting to climate change through local municipal planning: Barriers and challenges. Mitigation and Adaptation Strategies for Global Change, 16(8), 889-909. https://doi.org/10.1007/s11027-011-9301-2

Mees, H. (2017). Local governments in the driving seat? A comparative analysis of public and private responsibilities for adaptation to climate change in European and North-American cities. Journal of Environmental Policy \& Planning, 19(4), 374-390. https://doi.org/10.1080/1523908X.2016.1223540

Millner, A., \& Dietz, S. (2015). Adaptation to climate change and economic growth in developing countries. Environment and Development Economics, 20(03), 380-406. https://doi.org/10.1017/S1355770X14000692

Morce, J. M., Barrett, M., Mayan, M., Olson, K., \& Spiers, J. (2002). Verification Strategies for Establishing Reliability and Validity in Qualitative Research. International Journal of Qualitative Methods, 1(2), 13-22. 
https://doi.org/10.1177/160940690200100202

Moser, S. C., \& Ekstrom, J. A. (2010). A framework to diagnose barriers to climate change adaptation. Proceedings of the National Academy of Sciences, 107(51), 22026-22031. https://doi.org/10.1073/pnas.1007887107

National Institute of Statistics and Demography (INSD). (2017). Annuaire statistique, 2016. Retrieved from http://www.insd.bf/n/contenu/pub_periodiques/annuaires_stat/Annuaires_stat_nationaux_BF/Annuaire_stat 2016.pdf

Nelson, V. (2011). Gender, Generations, Social Protection and Climate Change: A Thematic Review. London: Overseas Development Institute. Neumayer, E. and Plümper.

Otieno, P. S., Ogutu, C. A., Mburu, J., \& Nyikal, R. A. (2017). Effect of Global-GAP policy on smallholder French beans farmers' climate change adaptation strategies in Kenya. African Journal of Agricultural Research, 12(8), 577-587. https://doi.org/10.5897/AJAR2017.12149

Ouédraogo, M. (2012). Impact des changements climatiques sur les revenus agricoles au Burkina Faso. Journal of Agriculture and Environment for International Development, 106(1), 3-21. https://doi.org/10.12895/jaeid.20121.43

Pandey, D. N., Gupta, A. K., \& Anderson, D. M. (2003). Rainwater Harvesting as an Adap-tation to Climate Change. Current Science, 85(1), 10, 46-59. Retrieved from http://repository.ias.ac.in/21926/1/21926.pdf

Panthou, G., Lebel, T., Vischel, T., Quantin, G., Sane, Y., Ba, A., ... Diopkane, M. (2018). Rainfall intensification in tropical semi-arid regions: The Sahelian case. Environmental Research Letters, 13, 064013. https://doi.org/10.1088/1748-9326/aac334

Salack, S., Sarr, B., Sangare, S. K., Ly, M., Sanda, I. S., \& Kunstmann, H. (2015). Crop-Climate Ensemble Scenarios to Improve Risk Assessment and Resilience in the Semi-Arid Regions of West Pays En Afrique. Climate Research, 65, 107-121. https://doi.org/10.3354/Cr01282

Schipper, E. L. F. (2006). Conceptual History of Adaptation in the UNFCCC Process. Review of European Community \& International Environmental Law, 15(1), 82-92. Retrieved from https://www.researchgate.net/profile/Lisa_Schipper/publication/229561547_Conceptual_history_of_adaptat ion_in_the_UNFCCC_process/links/59f2cad1 aca272cdc7d02ecd/Conceptual-history-of-adaptation-in-theUNFCCC-process.pdf

Schleypen, J. R., Saeed, F., Dayamba, S. D., Coulibaly, O. J. D., \& D’haen, S. (2019). Impacts des changements climatiques sur l'économie (Produit Intérieur Brut et valeurs ajoutées sectorielles) et sur la productivité agricole au Burkina Faso. Report produced under the project "Projet d'Appui Scientifique aux processus de Plans Nationaux d'Adaptation dans les pays francophones les moins avancés d'Afrique subsaharienne", Climate Analytics gGmbH, Berlin.

Shaw, J., Chiara, D., \& Stocker, L. (2013). Spanning the boundary between climate science and coastal communities: Opportunities and challenges. Ocean and Coastal Management, 86, 80-87. https://doi.org/10.1016/j.ocecoaman.2012.11.008

Sombié, I. (2019). Système de suivi-évaluation des actions climatiques au Burkina Faso. Report produced under the project "Projet d'Appui Scientifique aux processus de Plans Nationaux d'Adaptation dans les pays francophones les moins avancés d'Afrique subsaharienne", Deutsche Gesellschaft für Internationale Zusammenarbeit (GIZ), Berlin.

Sternlieb, F., Bixler, R. P., Huber-Stearns, H., \& Huayhuaca, C. (2013). A question of fit: Reflections on boundaries, organizations and social-ecological systems. Journal of Environmental Management, 130, 117-125. http://dx.doi.org/10.1016/j.jenvman.2013.08.053

Swai, O. W. (2017). Determinants of Adaptation to Climate Change: A Gendered Analysis from Bahi and Kondoa Districts, Dodoma Region, Tanzania. Journal of Sustainable Development, 10(2). https://doi.org/10.5539/jsd.v10n2p155

Swart, R. J., Biesbroek, G. R., Binnerup, S., Carter, T. R., Henrichs, T., \& Loquen, S. (2009). Europe Adapts to Climate change: Comparing National Adaptation Strategies (No. 01/2009). Helsinki: Finnish Environment Institute (SYKE).

Theokritoff, E., \& D'haen, S. (2019). État des lieux de l'intégration du changement climatique dans les politiques nationales d'adaptation et de développement au Burkina Faso. Report produced under the project "Projet d'Appui Scientifique aux processus de Plans Nationaux d'Adaptation dans les pays francophones les moins 
avancés d'Afrique subsaharienne", Climate Analytics gGmbH, Berlin.

Touré, H. A. (2016). Effect of climate change and variability on Pearl Millet (Pennisetum Glaucum (L.) R. Br.) production in the sudanian and sahelian agro-ecological zones in Mali. (Doctoral dissertation, Kwame Nkrumah University of Science and Technology, Kumasi, Ghana). Retrieved from http://ir.knust.edu.gh

Traore, S., \& Owiyo, T. (2013). Dirty droughts causing loss and damage in Northern Burkina Faso. International Journal of Global Warming, 5(4). https://doi.org/10.1504/IJGW.2013.057288

Uittenbroek, C. J. (2016). From Policy Document to Implementation: Organizational Routines as Possible Barriers to Mainstreaming Climate Adaptation. Journal of Environmental Policy \& Planning, 18(2), 161-176. https://doi.org/10.1080/1523908X.2015.1065717

Urwin, K., \& Jordan, A. (2008). Does public policy support or undermine climate change adaptation? Exploring policy interplay across different scales of governance. Global Environmental Change, 18(1), 180-191. https://doi.org/10.1016/j.gloenvcha.2007.08.002

Waongo, M., Lauxb, P., \& Kunstmann, H. (2015). Adaptation to climate change: The impacts of optimized planting dates on attainable maize yields under rainfed conditions in Burkina Faso. Agricultural and Forest Meteorology, 205, 23-39. https://doi.org/10.1016/j.agrformet.2015.02.006

Waters, E., Barnett, J., \& Puleston, A. (2014). Contrasting perspectives on barriers to adaptation in Australian climate change policy. Climatic Change, 124, 691-702. https://doi.org/10.1007/s10584-014-1138-8

Zidouemba, P. R., \& Gerard, F. (2018). Does Agricultural Productivity Actually Matter for Food Security in a Landlocked Sub-Saharan African Country? The Case of Burkina Faso. Canadian Journal of Agricultural Economics, 66(1), 103-142. https://doi.org/10.1111/cjag.12140

Zidouemba, R. P. (2017). Economy-wide Implications of Climate Change in Burkina Faso. Economics Bulletin, 37(4), 2797-2808. Retrieved from https://www.researchgate.net/profile/Patrice_Zidouemba/publication/321462178_Economywide_Implications_of_Climate_Change_in_Burkina_Faso/links/5aba1cd5aca2722b97d189d7/Economywide-Implications-of-Climate-Change-in-Burkina-Faso.pdf

\section{Copyrights}

Copyright for this article is retained by the author(s), with first publication rights granted to the journal.

This is an open-access article distributed under the terms and conditions of the Creative Commons Attribution license (http://creativecommons.org/licenses/by/4.0/). 